\title{
EFEK ALELOPATI EKSTRAK DAUN BABANDOTAN (Ageratum conyzoides L.) TERHADAP PERKECAMBAHAN DAN PERTUMBUHAN KECAMBAH PADI GOGO VARIETAS INPAGO 8
}

\author{
Elsi Diana $^{1^{*}}$, Zulkifli $^{2}$, TundjungTripeni Handayani ${ }^{3}$, Martha Lulus Lande ${ }^{4}$ \\ 1,2,3,4 Jurusan Biologi FMIPA Universitas Lampung, Indonesia \\ "E-mail: elsidianaa@gmail.com
}

Received: Mey 23 $3^{\text {rd }}$, 2019. Accepted: June $26^{\text {th }}$, 2019. Published: April $29^{\text {th }}, 2019$

\begin{abstract}
The purpose of this study was to prove that in the early phase of vegetative growth, the Inpago 8 upland rice was resistant to allelopathy from goat weed dry leaf extract (Ageratum conyzoides L.). This research was conducted in November - December 2018 at the Botanical Laboratory, Department of Biology, Faculty of Mathematics and Natural Sciences, University of Lampung. This study used the RAL method (Complete Random Design) with babandotan dry leaf extract as a supporting factor consisting of 5 levels of concentration namely $0 \% \mathrm{~b} / \mathrm{v}, 2.5 \% \mathrm{~b} / \mathrm{v}, 5 \% \mathrm{~b} / \mathrm{v}, 7.5 \% \mathrm{~b} / \mathrm{v}$, and $10 \% \mathrm{~b} / \mathrm{v}$ and consists of 5 replications. The parameters measured in this study were germination, shoot length, length weight, dry weight, relative water content, and chlorophyll a content, as well as total sprouts. Homogeneity of variance was determined by the Levene test at a real level of 5\%. Analysis of variance and BNJ test were carried out at 5\% level. The results of this study indicate that babandotan dry leaf extract did not show allelopathy on germination of Inpago 8 varieties of upland rice seeds. At a concentration of $7.5 \% \mathrm{~b} / \mathrm{v}$ stimulated the growth of Inpago 8 upland rice sprouts associated with increased shoot length and dry weight shoots.
\end{abstract}

Keywords: Goat weed, Ageratum conyzoides L., rice, Oryza sativa L., Allelopathy.

\begin{abstract}
ABSTRAK
Tujuan dari penelitian ini adalah membuktikan bahwa pada fase awal pertumbuhan vegetatif padi gogo varietas Inpago 8 tahan terhadap alelopati dari ekstrak daun kering babandotan (Ageratum conyzoides L.). Penelitian ini dilakukan pada bulan November - Desember 2018 di Laboratorium Botani Jurusan Biologi Fakultas Matematika dan Ilmu Pengetahuan Alam Universitas Lampung. Penelitian ini menggunakan metode RAL (Rancangan Acak Lengkap) dengan ekstrak daun kering babandotan sebagai faktor utamanyayang terdiri atas 5 taraf konsentrasi yaitu $0 \% \mathrm{~b} / \mathrm{v}, 2,5 \% \mathrm{~b} / \mathrm{v}, 5 \% \mathrm{~b} / \mathrm{v}, 7,5 \% \mathrm{~b} / \mathrm{v}$, dan $10 \% \mathrm{~b} / \mathrm{v}$ dan terdiri dari $5 \mathrm{kali}$ ulangan. Parameter yang diukur dalam penelitian ini adalah daya kecambah, panjang tunas, berat segar, berat kering,kadar air relatif, dan kandungan klorofil a,b serta total kecambah. Homogenitas ragam ditentukan dengan uji Levene pada taraf nyata 5\%. Analisis ragam dan uji BNJ dilakukan pada taraf nyata $5 \%$. Hasil penelitian ini menunjukkan bahwa ekstrak daun kering babandotan tidak bersifat alelopati terhadap perkecambahan benih padi gogo varietas Inpago 8 . Pada konsentrasi 7,5\% b/v menstimulasi pertumbuhan kecambah padi gogo Inpago 8 yang ditunjukkan oleh peningkatan panjang tunas dan berat segar tunas.
\end{abstract}

Kata kunci : Babandotan, Ageratum conyzoides L., Padi, Oryza sativa L., Alelopati. 


\section{PENDAHULUAN}

Konsumsi beras di Indonesia tergolong tinggi yaitu sebesar 97,4 kg/kapita/tahun pada tahun 2013. Kebutuhan beras terus meningkatkan karena peningkatan jumlah konsumen tidak diimbangi dengan produksi yang cukup (Statistik, 2014). Padi terbagi atas dua jenis yaitu padi kering (gogo) yang dapat ditanam pada dataran tinggi dan padi sawah yang ditanam pada dataran rendah dan dalam penanamannya memerlukan genangan air (Prasetiyo, 2002). Salah satu varietas padi gogo yang berpotensi adalah Inpago 8 yang berumur singkat, produksi tanaman tinggi, rasa nasi yang pulen, tahan terhadap wereng coklat tipe 2 dan 3, hasil 3,6-5,6 t/ha dan umur 110-120 hari (Lesmana, Toha, Las, \& Suprihatno, 2004)

Salah satu masalah yang dihadapi padi gogo adalah gulma yang menghasilkan senyawa alelopati yang dapat mempengaruhi pertumbuhan dan perkembangan padi gogo.Alelopati adalah senyawa - senyawa kimia yang dilepaskan oleh tumbuhan ke lingkungan, senyawa ini dikenal juga dengan zat alelokimia (Utama, 2017). Salah satu gulma yang menghasilkan senyawa alelopati adalah babandotan (Ageratum conyzoides L.), daun babandotan diidentifikasi mengandung 3 phenolic acid yaitu gallic acid, comalid acid, dan protocatechuic acid yang dapat menghambat beberapa gulma pada tanaman padi (Hong, Xuan, Eiji, \& Khanh, 2004)

Menurut beberapa penelitian yang menggunakan daun babandotan (Ageratum conyzoides L.) yaitu seperti penelitian (Siti Hafsah, Ulim, \& Nofayanti, 2013) menunjukkan bahwa cairan perasan daun babandotan (Ageratum conyzoides L.) pada konsentrasi $100 \mathrm{~g} / \mathrm{l}$ sudah dapat menghambat perkecambahan, bahkan pada konsentrasi $500 \mathrm{~g} / \mathrm{l}$ dapat menghambat perkecambahan $100 \%$.Tujuan dari penelitian ini adalah membuktikan bahwa pada fase awal pertumbuhan vegetatif padi gogo varietas Inpago 8 tahan terhadap alelopati dari ekstrak daun kering babandotan (Ageratum conyzoides $\mathrm{L}$.)

Berdasarkan penelitian di atas, maka terdapat perbedaan antara penelitian tersebut dengan penelitian ini bahwa penelitian ini lebih menggunakan ekstrak daun kering babandotan, sedangkan pada penelitian di atas menggunakan cairan perasan daun babandotan.

\section{METODE PENELITIAN}

Penelitian ini dilaksanakan di Laboratorium Botani Jurusan Biologi, Fakultas Matematika dan Ilmu Pengetahuan Alam, Universitas Lampung pada bulan November - Desember 2018. Alat yang digunakan dalam penelitian ini adalah erlenmeyer, gelas uku, beaker glass, tabung reaksi dan raknya, corong, mortar dan penumbuknya, batang pengaduk, nampan plastik, gelas plastik, kantung plastik, penggaris, pinset, kertas saring Whatman no.1, sentrifugasi, neraca digital, spektrofotometri UV, oven, kertas label, gunting. Bahan yang digunakan dalam penelitian ini adalah daun babandotan yang diperoleh dari Bandar Lampung, benih padi gogo varietas Inpago 8 yang diperoleh dari pak Widodo (BPTP Lampung), akuades, dan etanol 96\%.

Percobaan ini dilaksanakan dalam Rancangan Acak Lengkap (RAL) dengan ekstrak air daun rumput babandotan (Ageratum conyzoides L.) sebagai faktor utama yang terdiri atas 5 taraf konsentrasi : $0 \% \mathrm{~b} / \mathrm{v}$ (kontrol), 2,5\% b/v, $5 \% \mathrm{~b} / \mathrm{v}, 7,5 \% \mathrm{~b} / \mathrm{v}$ dan $10 \% \mathrm{~b} / \mathrm{v}$ dengan 5 ulangan. Variabel bebas dalam penelitian ini adalah konsentrasi ekstrak air daun babandotan (Ageratum conyzoides L.), sedangkan variabel terikat penelitian ini adalah daya kecambah, panjang tunas, berat segar, berat kering, rasio tunas akar,kadar air relatif, dan kandungan klorofil (a,b dan total). Sebagai parameter dalam penelitian ini adalah nilai tengah $(\mu)$ semua variabel. Penyiapan daun babandotan dicuci bersih lalu dikering anginkan selama seminggu. Kemudian daun dihaluskan dengan blender sehingga diperoleh serbuk daun kering babandotan. Setelah halus, serbuk diayak dengan ayakan tepung sehingga diperoleh serbuk halus yang homogen.Untuk memaksimalkan metabolit sekunder bubuk daun kering babandotan yang larut dalam aquades maka larutan diinkubasi selama 24 jam pada suhu kamar. Larutan disaring dengan kertas saring Whatman no.1 ke dalam beaker glass 
sehingga diperoleh larutan yang jernih.Untuk mendapatkan benih yang baik maka benih direndam dalam aquades selama 10 menit. Benih yang tidak baik akan mengapung dan dibuang, sedangkan benih yang baik akan tenggelam dan diambil untuk dikecambahkan. Benih yang telah diseleksi akan direndam ke dalam 5 konsentrasi ekstrak air daun babandotan yaitu $0 \% \mathrm{~b} / \mathrm{v}$ (kontrol), 2,5\% b/v, 5\% $\mathrm{b} / \mathrm{v}, 7,5 \% \mathrm{~b} / \mathrm{v}$ dan $10 \% \mathrm{~b} / \mathrm{v}$ selama $24 \mathrm{jam}$. Setelah 24 jam direndam, benih dikecambahkan dalam 5 nampan plastik yang dilapisi dengan kapas dan dibasahi oleh aquades. Jumlah benih yang digunakan pada penelitian ini adalah 500 butir benih padi gogo varietas inpago 8, dengan 100 butir benih padi pada setiap nampan. Jumlah benih padi yang berkecambah dihitung setelah 7 hari penaburan benih (Matthews \& Powell, 2006).

Gelas plastik dalam percobaan digunakan sebagai wadah untuk penanaman benih yang telah berkecambah sebanyak 25 buah gelas. Gelas plastik diberi label dengan notasi perlakuan dan ulangan. Pada bagian dasar gelas plastik dilapisi kapas dan dibasahi dengan aquades, benih yang telah berkecambah dipindahkan ke dalam gelas plastik, masing-masing gelas plastik berisikan 2 kecambah padi.Setiap gelas plastik diberi ekstrak air daun babandotan sebanyak $10 \mathrm{ml}$ dan pengamatan variabel kecambah pada penelitian ini dilakukan 7 hari setelah penanaman. Pengamatan pada penelitian ini meliputi daya kecambah, panjang tunas, berat segar, berat kering, rasio tunas akar,kadar air relatif, dan kandungan klorofil (a,b dan total). Setelah 7 hari penanaman maka panjang tunas dapat diukur dari pangkal sampai ujung daun menggunakan penggaris (satuan $\mathrm{cm}$ ). Pengukuran berat segar kecambah padi ditimbang menggunakan timbangan digital dan dinyatakan dalam satuan miligram.Kecambah padi yang telah diukur berat segarnya, dikeringkan menggunakan oven dengan suhu $130^{\circ} \mathrm{C}$ selama 2 jam (ALUMUNIUM \& TRIYANA, n.d.) supaya kadar air dalam kecambah menghilang. Kemudian kecambah ditimbang kembali menggunakan timbangan digital untuk mengukur berat kering yang dinyatakan dalam satuan miligram.kadar air relatif ditentukan dalam rumus :

$$
\text { Kadar Air Relatif }=\frac{M 1-M 2}{M 1} \times 100 \%
$$

Keterangan : $\mathrm{M}_{1}=$ Berat Segar Kecambah

$$
\mathrm{M}_{2}=\text { Berat Kering Kecambah }
$$

Ketentuan kandungan klorofil menurut (Miazek, 2002), 0,01 gram daun padi digerus didalam mortar sampai halus, kemudian ditambahkan larutan etanol $96 \%$ sebanyak $5 \mathrm{ml}$. Selanjutnya ekstrak disaring ke dalam tabung reaksi. Diukur absorbansi dari ekstrak klorofil dengan panjang gelombang 649 dan $665 \mathrm{~nm}$.

Perhitungan kandungan klorofil (mg/L) ditentukan dengan rumus :

$$
\begin{gathered}
\text { Chla }=13,36 \mathrm{~A}_{665}-5,19 \mathrm{~A}_{649} \frac{v}{w \times 1000} \\
\text { Chlb }=27,43 \mathrm{~A}_{649}-8,12 \mathrm{~A}_{665} \frac{v}{w \times 1000} \\
\text { Chltotal }=22,24 \mathrm{~A}_{649}-5,24 \mathrm{~A}_{665} \frac{v}{w \times 1000}
\end{gathered}
$$

\section{Keterangan :}

$\begin{array}{ll}\text { Chla } & \text { : klorofil a } \\ \text { Chlab } & \text { : klorofil b } \\ \text { Chlatotal } & \text { : klorofil total } \\ \mathrm{A}_{665} & \text { : absorbansi pada panjang gelombang } 665 \\ \mathrm{~A}_{649} & \text { : absorbansi pada panjang gelombang } 649 \\ \mathrm{~V} & \text { : Volume etanol } \\ \mathrm{W} & \text { : Berat daun }\end{array}$


Setelah 7 hari penanaman maka panjang akar diukur dari pangkal sampai ujung akan menggunakan penggaris dinyatakan dalam $\mathrm{cm}$ (Statistik, 2014). menyatakan bahwa benih padi yang telah berkecambah selama 7 hari dihitung persentase perkecambahan dengan cara:

$$
\text { Daya kecambah }=\frac{\sum \text { beni } h \text { yang berkecamba } h}{\sum \text { beni } h \text { yang ditanam }} \times 100
$$

Homogenitas ragam ditentukan dengan uji Levene pada taraf nyata 5\%.Analisis ragam dan uji BNJ dilakukan pada taraf nyata $5 \%$.Korelasi antara konsentrasi ekstrak air daun babandotan dengan variabel pertumbuhan ditentukan berdasarkan degradasi linier.keeratan hubungan tersebut ditentukan pada nilai koefisien korelasi atau r.

\section{HASIL DAN PEMBAHASAN}

Daya Kecambah. Persentase benih padi gogo varietas Inpago 8 yang berkecambah 7 hari setelah perlakuan ekstrak air daun kering babandotan ditunjukkan pada Gambar 1.

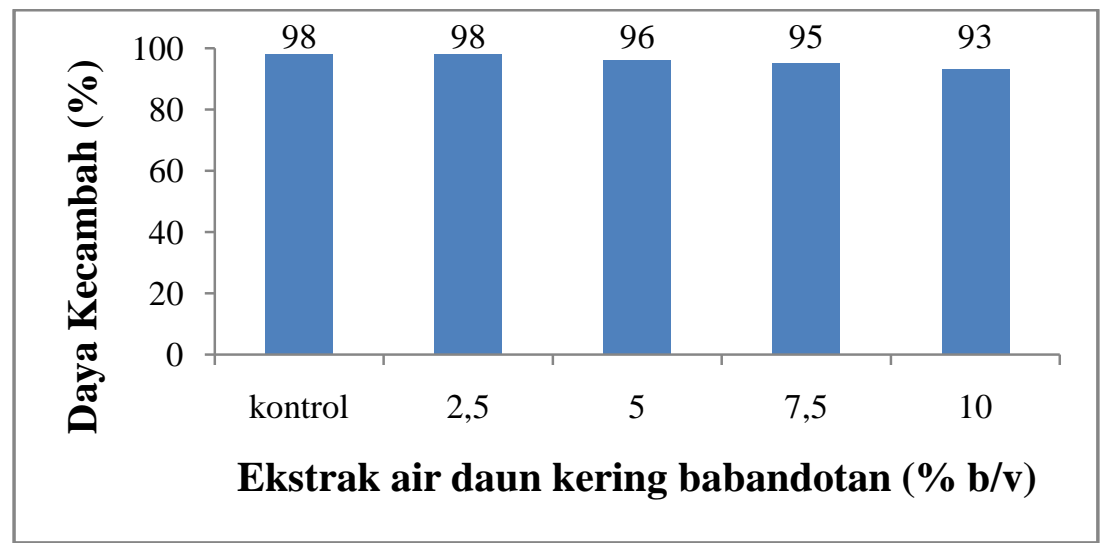

Gambar 1. Persentase Benih Padi Gogo Inpago 8 yang Berkecambah setelah Perlakuan Ekstrak Air Daun Kering Babandotan

Gambar 1 di atas menunjukkan bahwa ekstrak air daun kering babandotan relatif tidak mempengaruhi daya kecambah benih padi gogo varietas Inpago 8. Pada kisaran konsentrasi ekstrak $2,5 \%$ - 10\% daya kecambah benih padi gogo varietas Inpago 8 adalah 98-93\%.

Panjang Tunas.Rata-rata panjang tunas kecambah padi gogo varietas Inpago 814 hari setelah perlakuan ekstrak air daun kering babandotan ditunjukkan pada tabel 1. Uji Levene pada taraf nyata $5 \%$ menunjukkan bahwa ragam populasi adalah homogen $(\mathrm{p}>0,05)$. Analisis ragam pada taraf nyata 5\% menunjukkan bahwa ekstrak air daun kering babandotan berpengaruh nyata terhadap panjang tunas kecambah padi gogo Inpago $8(\mathrm{p}<0,05)$.

Tabel 1. Efek Ekstrak Air Daun Kering Babandotan Terhadap Panjang Tunas Kecambah Padi Gogo Varietas Inpago 8

\begin{tabular}{cc}
\hline Konsentrasi Ekstrak (\%) & Panjang Tunas $(\mathbf{c m}) \overline{\mathbf{Y}} \pm \mathbf{S E}$ \\
\hline Kontrol & $11,16 \pm 0,24^{\mathrm{a}}$ \\
2,5 & $10,86 \pm 0,26^{\mathrm{a}}$ \\
5 & $10,88 \pm 0,19^{\mathrm{a}}$ \\
7,5 & $13,44 \pm 0,25^{\mathrm{b}}$ \\
10 & $12,88 \pm 0,25^{\mathrm{b}}$ \\
\hline
\end{tabular}


Keterangan : Nilai-nilai yang diikuti oleh huruf-huruf yang sama tidak berbeda nyata. HSD $0,05=1,01$

Uji BNJ pada taraf nyata 5\% menunjukkan bahwa panjang tunas kontrol berbeda nyata dari panjang tunas perlakuan $7,5 \%$ dan $10 \%$. Demikian juga panjang tunas perlakuan $2,5 \%$ dan $5 \%$ berbeda nyata dari panjang tunas 7,5\% dan $10 \%$. Hubungan antara konsentrasi ekstrak air daun kering babandotan dengan panjang tunas kecambah padi gogo varietas Inpago 8 ditunjukkan pada gambar 2 .

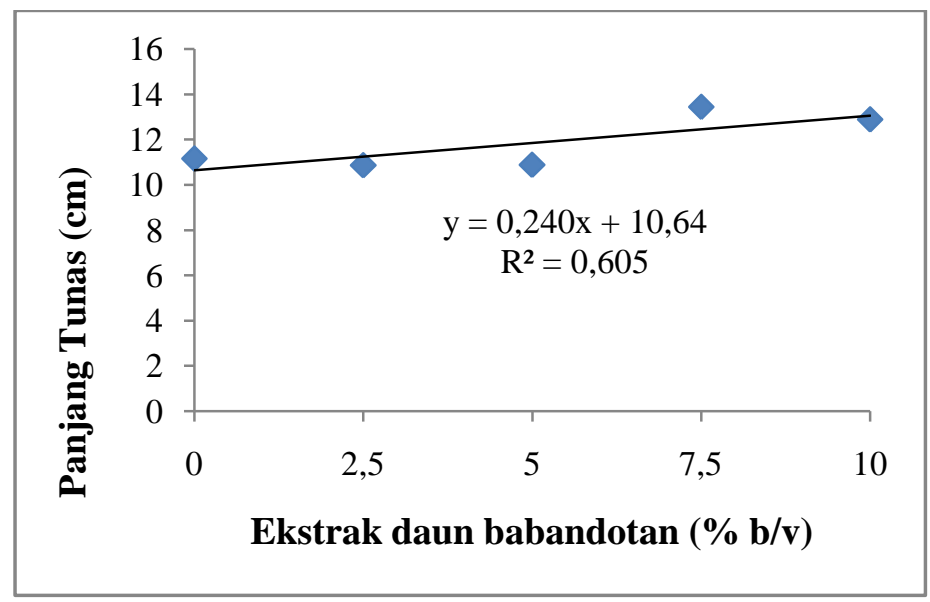

Gambar 2. Hubungan antara konsentrasi ekstrak air daun kering babandotan dengan panjang tunas kecambah padi gogo varietas Inpago 8.

Ekstrak air daun kering babandotan berkolerasi linier positif dengan panjang tunas kecambah padi gogo Inpago 8 dengan persamaan garis $y=0,2408 x+10,64$. Koefisien determinasi $\left(\mathrm{R}^{2}\right)$ adalah 0,6054 sedangkan koefisien korelasi (r) adalah 0,78 yang menunjukkan hubungan yang kuat (strong relationship) antara ekstrak air daun kering babandotan dengan panjang tunas kecambah padi gogo Inpago 8.

Berat Segar Tunas.Rata-rata berat segar tunas kecambah padi gogo varietas Inpago 814 hari setelah perlakuan ekstrak air daun kering babandotan ditunjukkan pada tabel 2. Uji Levene pada taraf nyata $5 \%$ menunjukkan bahwa ragam populasi adalah homogen $(p>0,05)$. Analisis ragam pada taraf nyata 5\% menunjukkan bahwa ekstrak air daun kering babandotan berpengaruh nyata terhadap berat segar tunas kecambah padi gogo varietas Inpago $8(\mathrm{p}<0,05)$.

Tabel 2. Efek Ekstrak Air Daun Kering Babandotan Terhadap Berat Segar Tunas Kecambah Padi Gogo Varietas Inpago 8

\begin{tabular}{cc}
\hline Konsentrasi Ekstrak $(\%)$ & Berat Segar Tunas $(\mathrm{g}) \overline{\mathrm{Y}} \pm \mathrm{SE}$ \\
\hline Kontrol & $8,04 \pm 0,68^{\mathrm{a}}$ \\
2,5 & $7,80 \pm 0,52^{\mathrm{a}}$ \\
5 & $7,90 \pm 0,33^{\mathrm{a}}$ \\
7,5 & $11,50 \pm 0,54^{\mathrm{b}}$ \\
10 & $9,72 \pm 0,57^{\mathrm{a}}$
\end{tabular}

Keterangan : Nilai-nilai yang diikuti dengan huruf yang sama tidak berbeda nyata. BNJ $0,05=2,29$.

Uji BNJ pada taraf nyata 5\% menunjukkan bahwa berat segar tunas kontrol berbeda nyata dari berat segar tunas perlakuan 7,5\%. Demikian juga berat segar tunas perlakuan $2,5 \%, 5 \%$ dan $10 \%$ berbeda nyata dari berat segar tunas $7,5 \%$. Hubungan antara konsentrasi ekstrak air daun 
kering babandotan dengan berat segar tunas kecambah padi gogo Inpago 8 ditunjukkan pada gambar 3.

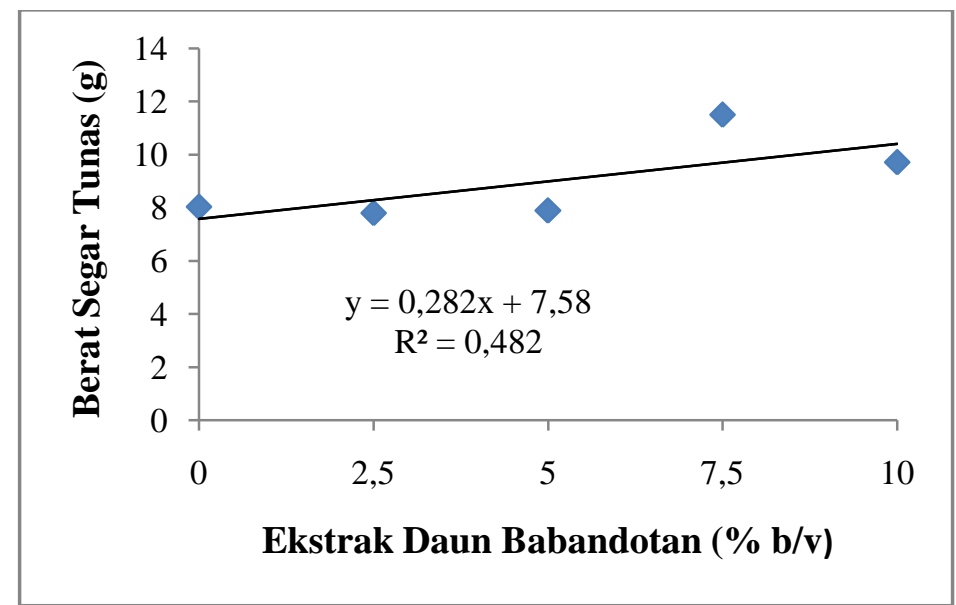

Gambar 3. Hubungan antara Konsentrasi Ekstrak Air Daun Kering Babandotan dengan Berat Segar Tunas Kecambah Padi Gogo Inpago 8.

Ekstrak air daun babandotan berkolerasi linier positif dengan berat segar tunas kecambah padi gogo Inpago 8 dengan persamaan garis $y=0,2408 x+7,58$. Koefisien determinasi $\left(\mathrm{R}^{2}\right)$ adalah 0,4821 sedangkan koefisien korelasi (r) adalah 0,69 yang menunjukkan hubungan yang moderat (moderate relationship) antara ekstrak air daun kering babandotan dengan berat segar tunas kecambah padi gogo Inpago 8.

Berat Kering Tunas. Rata-rata berat segar tunas kecambah padi gogo varietas Inpago 814 hari setelah perlakuan ekstrak air daun kering babandotan ditunjukkan pada tabel 3. Uji Levene pada taraf nyata 5\% menunjukkan bahwa ragam populasi adalah homogen $(p>0,05)$. Analisis ragam pada taraf nyata 5\% menunjukkan bahwa ekstrak air daun kering babandotan berpengaruh nyata terhadap berat kering tunas kecambah padi gogo varietas Inpago $8(p<0,05)$.

Tabel 3. Efek Ekstrak Air Daun Kering Babandotan Terhadap Berat Segar Tunas Kecambah Padi Gogo Varietas Inpago 8

\begin{tabular}{cc}
\hline Konsentrasi Ekstrak (\%) & Berat Kering Tunas $(\mathrm{g}) \overline{\mathrm{Y}} \pm \mathrm{SE}$ \\
\hline Kontrol & $5,70 \pm 0,41^{\mathrm{a}}$ \\
2,5 & $5,52 \pm 0,30^{\mathrm{ab}}$ \\
5 & $5,92 \pm 0,17^{\mathrm{a}}$ \\
7,5 & $6,94 \pm 0,40^{\mathrm{ac}}$ \\
10 & $6,84 \pm 0,24^{\mathrm{a}}$
\end{tabular}

Keterangan : Nilai-nilai yang diikuti huruf yang sama tidak berbeda nyata. BNJ $0,05=1,35$

Uji BNJ pada taraf nyata 5\% menunjukkan bahwa berat kering tunas kontrol tidak berbeda nyata dari berat kering tunas semua perlakuan. berat kering tunas perlakuan $2,5 \%$ berbeda nyata dari berat segar tunas 7,5\%. Hubungan antara konsentrasi ekstrak air daun kering babandotan dengan berat kering tunas kecambah padi gogo varietas Inpago 8 ditunjukkan pada gambar 4 . 


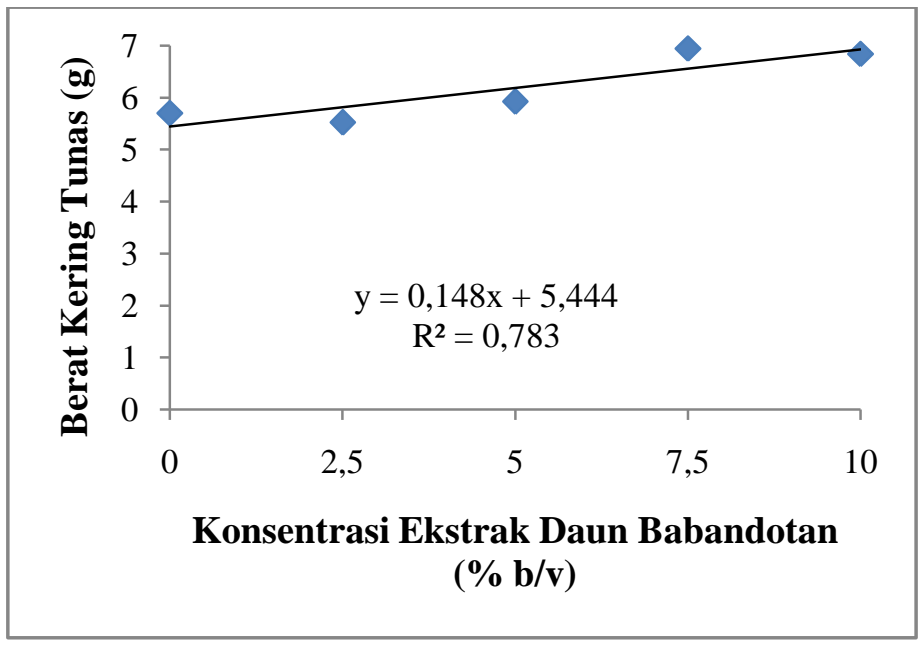

Gambar 4. Hubungan antara Konsentrasi Ekstrak Air Daun Kering Babandotan Dengan Berat Kering Tunas Kecambah Padi Gogo Varietas Inpago 8

Ekstrak air daun babandotan berkolerasi linear positif dengan berat kering tunas kecambah padi gogo Inpago 8 dengan persamaan garis $y=0,148 x+5,444$. Koefisien determinasi $\left(\mathrm{R}^{2}\right)$ adalah 0,7838 sedangkan koefisien korelasi (r) adalah 0,88 yang menunjukkan hubungan yang kuat (strong relationship) antara ekstrak air daun kering babandotan dengan berat kering tunas kecambah padi gogo varietas Inpago 8.

Berat segar total. Rata-rata berat segar total kecambah padi gogo varietas Inpago 814 hari setelah perlakuan ekstrak air daun kering babandotan ditunjukkan pada tabel 4 . Uji Levene pada taraf nyata 5\% menunjukkan bahwa ragam populasi adalah homogen ( $\mathrm{p}>0,05)$. Analisis ragam pada taraf nyata 5\% menunjukkan bahwa ekstrak air daun kering babandotan tidak berpengaruh nyata terhadap berat segar total kecambah padi gogo varietas Inpago $8(\mathrm{p}>0,05)$

Tabel 4. Efek ekstrak air daun kering babandotan terhadap berat segar total kecambah padi gogo varietas Inpago 8

\begin{tabular}{cc}
\hline Konsentrasi Ekstrak $(\%)$ & Berat Segar Total $(\mathrm{g}) \overline{\mathrm{Y}} \pm \mathrm{SE}$ \\
\hline Kontrol & $12,70 \pm 0,70^{\mathrm{a}}$ \\
2,5 & $11,76 \pm 1,01^{\mathrm{ab}}$ \\
5 & $11,92 \pm 0,45^{\mathrm{ab}}$ \\
7,5 & $15,80 \pm 0,58^{\mathrm{ac}}$ \\
10 & $13,96 \pm 1,09^{\mathrm{a}}$
\end{tabular}

Keterangan : Nilai-nilai yang diikuti oleh huruf yang sama tidak berbeda nyata. BNJ $0,05=3,41$

Hubungan antara konsentrasi ekstrak air daun kering babandotan dengan berat segar kecambah padi gogo varietas Inpago 8 ditunjukkan pada Gambar 5. 


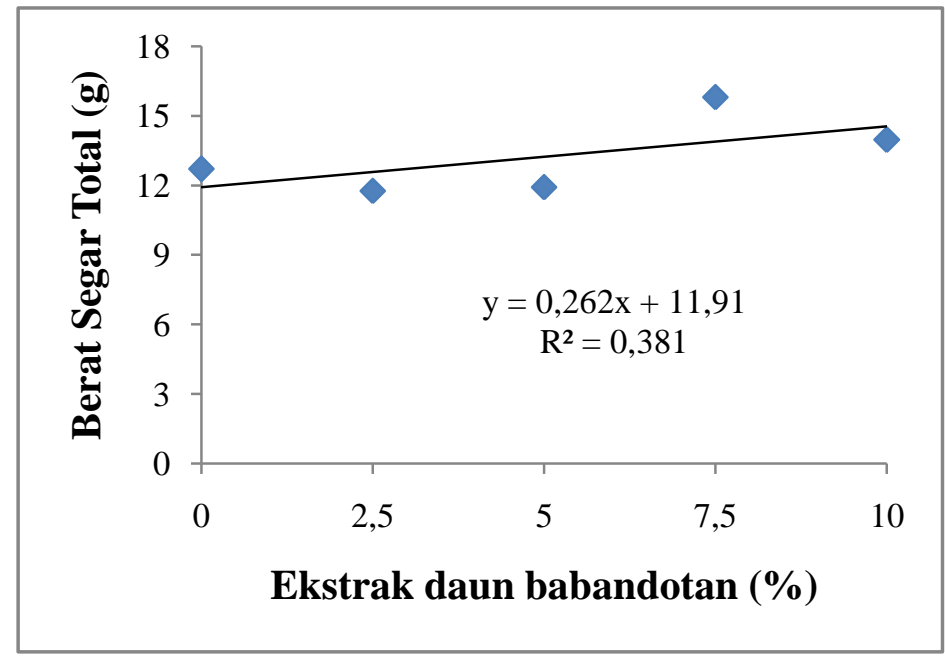

Gambar 5. Hubungan antara Konsentrasi Ekstrak Air Daun Kering Babandotan Dengan Berat Segar Kecambah Padi Gogo Varietas Inpago 8

Konsentrasi ekstrak air daun babandotan berkolerasi linear positif dengan berat segar kecambah padi gogo varietas Inpago 8 dengan persamaan garis $y=0,148 x+5,444$. Koefisien determinasi $\left(\mathrm{R}^{2}\right)$ adalah 0,7838 sedangkan koefisien korelasi (r) adalah 0,88 yang menunjukkan hubungan yang kuat (strong relationship) antara ekstrak air daun kering babandotan dengan berat kering tunas kecambah padi gogo varietas Inpago 8.

Pertumbuhan vegetatif awal atau pertumbuhan suatu kecambah dapat dievaluasi berdasarkan panjang tunas, berat segar, atau berat kering kecambah. Pertumbuhan memanjang pada kecambah diasosiasikan dengan pertumbuhan primer. Sel-sel didaerah apikal meristem membelah secara terus menerus yang diikuti dengan ekspansi sel sehingga menghasilkan suatu pertumbuhan primer atau pertumbuhan memanjang dari kecambah.Karena ekstrak menstimulasi pertumbuhan panjang tunas maka secara fisiologis dapat diduga bahwa ekstrak daun kering babandotan tidak hanya mengandung alelokimia yang bersifat menghambat tetapi juga mengandung alelokimia yang bersifat menstimulasi pertumbuhan. Beberapa hormon pertumbuhan tanaman diketahui sering kali terdapat pada ekstrak tanaman yang bersifat aktif pada konsentrasi rendah.Idu dan Ovuakporie 2013 melaporkan bahwa ekstrak air daun kering Ageratum conyzoides L. dengan konsentrasi 250 sampai 1000 ppm tidak berpengaruh terhadap persentase perkecambahan tanaman Sesanum indicum L.

\section{KESIMPULAN DAN SARAN}

Berdasarkan penelitian ini diperoleh kesimpulan yaitu bahwa ekstrak air daun kering babandotan tidak bersifat alelopati terhadap perkecambahan benih padi gogo varietas Inpago 8 . Pada konsentrasi $7,5 \%$ b/v menstimulasi pertumbuhan kecambah padi gogo Inpago 8 yang ditunjukkan oleh peningkatan panjang tunas dan berat segar tunas. Ekstrak air daun kering babandotan tidak bersifat alelopati terhadap kandungan klorofil kecambah padi gogo varietas Inpago 8.

Saran yang diajukan untuk penelitian selanjutnya adalah perlu dilakukan penelitian terhadap efek stimulasi ekstrak air daun kering babandotan terhadap kecambah padi gogo varietas lainnya. 


\section{DAFTAR PUSTAKA}

Alumunium, B. P. K. C., \& Triyana, M. (N.D.). Efek Ekstrak Daun Kirinyuh (Chromolaena Odorata [L.] Rm King \& H. Rob.) Terhadap Pertumbuhan Padi Gogo (Oryza Sativa L.) Varietas Situ.

Hong, N. H., Xuan, T. D., Eiji, T., \& Khanh, T. D. (2004). Paddy Weed Control By Higher Plants From Southeast Asia. Crop Protection, 23(3), 255-261.

Lesmana, O. S., Toha, H. M., Las, I., \& Suprihatno, B. (2004). Deskripsi Varietas Unggul Baru Padi. Balai Penelitian Tanaman Padi Sukamandi, 68.

Matthews, S., \& Powell, A. (2006). Electrical Conductivity Vigour Test: Physiological Basis And Use. Seed Testing International, 131, 32-35.

Miazek, K. (2002). Chlorophyll Extraction From Harvested Plant Material. Access Mode: Http://Chps. Fsid. Cvut. Cz/Pt/2011/Pdf/1100011-1. Pdf Quantitative Content Of Lawsone In The Methanolic Extracts Of Samples, 3(4), 5.

Prasetiyo, Y. T. (2002). Budi Daya Padi Sawah Tanpa Olah Tanah. Kanisius.

Siti Hafsah, H., Ulim, M. A. U., \& Nofayanti, C. M. (2013). Efek Alelopati Ageratum Conyzoides Terhadap Pertumbuhan Sawi. Jurnal Floratek, 8(1), 18-24.

Statistik, B. P. (2014). Produksi Padi, Jagung, Dan Kedelai (Angka Ramalan I Tahun 2014). Berita Resmi Statistik, (50/07).

Utama, M. Z. H. (2017). Tanggap Varietas Kacang Hijau Pada Perlakuan Ekstrak Rhizoma. Jurnal Embrio, 1(01), 21-28. 